\title{
THE APPLICATION OF GRAPHOLOGY AND ENNEAGRAM TECHNIQUES IN DETERMINING PERSONALITY TYPE BASED ON HANDWRITING FEATURES
}

\author{
Dian Pratiwi, Gatot Budi Santoso, Fiqih Hana Saputri
}

\author{
Trisakti University, Jl. Kyai Tapa No.1 Jakarta Barat, Indonesia \\ E-mail: dian.pratiwi@trisakti.ac.id
}

\begin{abstract}
This research was conducted with the aim of developing previous studies that have successfully applied the science of graphology to analyze digital handwriting and characteristics of his personality through shape based feature extraction, which in the present study will be applied one method of psychological tests commonly used by psychologists to recognize human's personality that is Enneagram. The Enneagram method in principle will classify the personality traits of a person into nine types through a series of questions, which then calculated the amount of the overall weight of the answer. Thickness is what will provide direction personality type, which will then be matched with the personality type of the result of the graphology analysis of the handwriting. Personality type of handwritten analysis results is processed based on the personality traits that are the result of the identification of a combination of four dominant form of handwriting through the software output of previous studies, that Slant (tilt writing), Size (font size), Baseline, and Breaks (respite each word). From the results of this research can be found there is a correlation between personality analysis based on the psychology science to the graphology science, which results matching personality types by $81.6 \%$ of 49 respondents data who successfully tested.
\end{abstract}

Keywords: Graphology, Enneagram, Psychology, Personality, Handwritten.

\begin{abstract}
Abstrak
Penelitian ini dilakukan dengan tujuan untuk mengembangkan penelitian sebelumnya yang telah berhasil menerapkan ilmu grafologi untuk menganalisis tulisan tangan digital dan karakteristik kepribadiannya melalui ekstraksi fitur berdasarkan bentuk, yang dalam penelitian ini akan diterapkan salah satu metode tes psikologi yang umum digunakan oleh psikolog untuk mengenali kepribadian manusia yang Enneagram. Enneagram Metode pada prinsipnya akan mengklasifikasikan sifat-sifat kepribadian seseorang menjadi sembilan jenis melalui serangkaian pertanyaan, yang kemudian dihitung jumlah berat keseluruhan jawabannya. Ketebalan inilah yang akan menyediakan jenis arah kepribadian, yang kemudian akan dicocokkan dengan tipe kepribadian dari hasil analisis grafologi dari tulisan tangan. tipe kepribadian dari hasil analisis tulisan tangan diproses berdasarkan ciri-ciri kepribadian yang merupakan hasil dari identifikasi kombinasi dari empat bentuk dominan dari tulisan tangan melalui output software dari penelitian sebelumnya, bahwa Slant (menulis tilt), Size (ukuran font), dasar, dan Breaks (tangguh setiap kata). Dari hasil penelitian ini dapat ditemukan ada korelasi antara analisis kepribadian berdasarkan ilmu psikologi dengan ilmu grafologi, yang menghasilkan tipe kepribadian yang cocok dengan 81,6\% dari 49 responden Data yang berhasil diuji.
\end{abstract}

Kata Kunci: Grafologi, Enneagram, Psikologi, Kepribadian, tulisan tangan.

\section{Introduction}

Generally, the recognation or tests a human's personality is done by implementing a variety of methods in psychology, such as DAP test, MBTI, Wartegg, MAPP, Baum Tree with the intent and specific purpose, such as for the recruitment of new employees to fit the field of the selected job, requirements to go to college for prospective students and others. Each type of test can not be done in a single (only one method) and the result would only be known by psychologists through a series of lengthy analysis and takes time. This is the main reason for researchers to develop further research on the science of personality through handwriting analysis, in order to be able to replace conventional ways, namely through a psychological analysis with a shape feature extraction method based on science of graphology.

From the results of previous studies entitled 'Application of Graphology Science in Developing Handwritten Analyzer Device based on Shape Feature Extraction'[17], researchers have success- 
12 Jurnal Ilmu Komputer dan Informasi (Journal of Computer Science and Information), Volume 10, Issue 1, June 2017

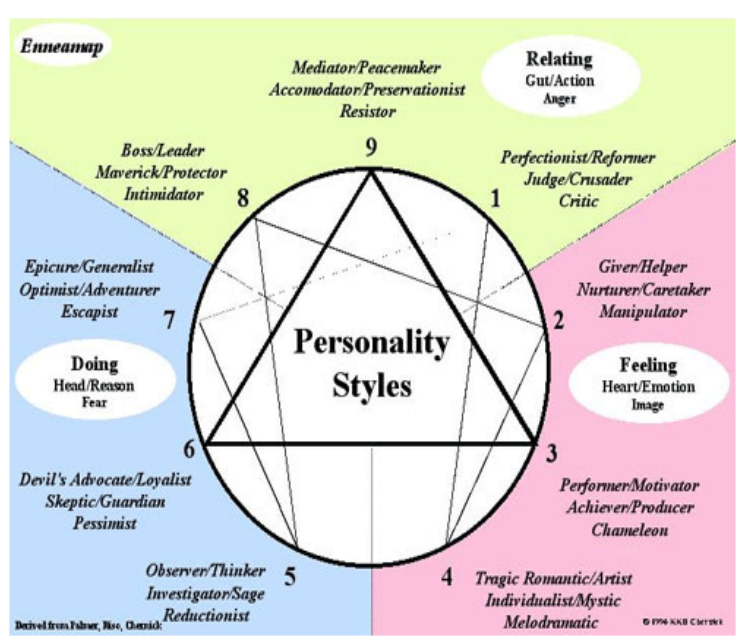

Figure 1. Personality Types based on Enneagram

fully developed a software that can provide results predominant form of a set of handwritten digital tested and the analysis of his personality to the level accuracy of $62.3-63.3 \%$. The personality analysis obtained through the implementation of clustering methods, shape-based feature extraction, and the science of graphology to 23 authors (handwriting). However, the result of these studies obtained also some drawbacks such a side validation is only based on the results of the analysis of graphologists named Clifford Howard [8], and the type of personality that represented only through four categories of the dominant form of handwriting that size, slant, breaks, and baseline. Shortage is what researchers want to improve by trying to complete through the Enneagram method, in which the test results were expected to be able to prove the validity of the graphology science in recognizing one's personality and how big the accuracy of the software that was developed after matching with the science of psychology.

Enneagram method is one of psychology method that uses a series of questions to determine a human's personality (Figure 1). In addition to the Enneagram, there are several other types of tests. However, it's categorized as a method Enneagram personality test is most accurate when compared with the method or type of other questionnaire based test, with the percentage of accuracy between $80-87 \%$ [16][14]. This is because the method of assessing the Enneagram personality types based on the experience of someone who happened since early age. This is the reason researchers uses the Enneagram method in the study of psychology as a basic reference for assessing a human's personality that will be matched with the results of the personality assessment of the graphology science.

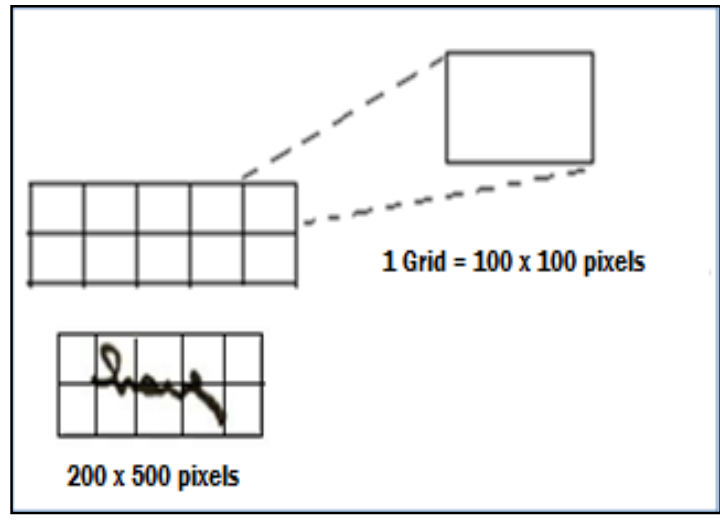

Figure 2. Sample of ROI Process

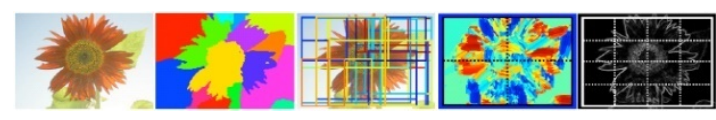

Figure 3. ROI Formation [7]

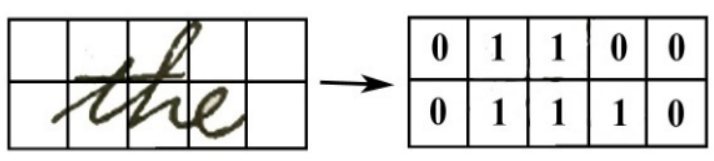

Figure 4. Sample of ROI Process

\section{Methods}

\section{Preprocessing}

An early stage that needs to be done to get the post data in digital form with the size of the pixel and gray level values or the same gray level of a set of handwritten analog that has been digitized through the scanner. This phase consists of the conversion of RGB colors to greyscale and thresholding.

\section{RGB to Greyscale Color Conversion}

RGB color conversion to greyscale is the stage for 24-bit color values to 8 bits, so the size of the resulting color will be smaller with the interval between 0 and 255 [2] :

$$
R G B=\frac{R+G+B}{3}
$$

where $R$ is the pixel value of red color, $G$ is the pixel value of green, and $B$ is the pixel value of blue color.

\section{Thresholding}

Thresholding is a process to separate the object region (foreground) to the background area over a certain threshold value [6]. In this study, the threshold value is also determined by trial and error. 


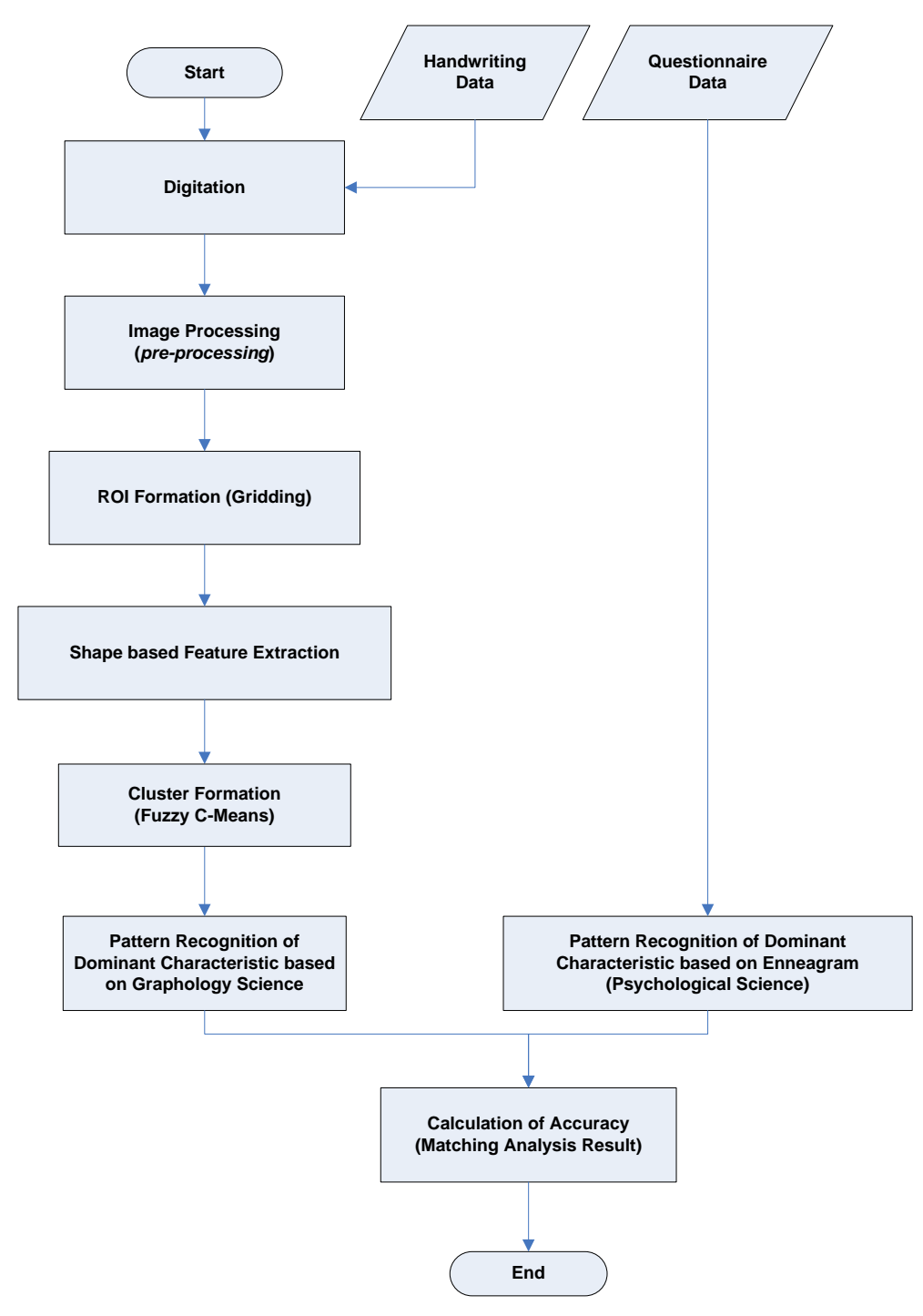

Figure 5. Research Flowchart

\section{Formation of ROI}

Formation of ROI (Region of Interest) is a technique that is generally done to help the analysis of the object to be observed, such as fMRI image analysis conducted by researchers from the UCLA - Los Angeles, Russel A. Poldrack in 2007 [5]. This technique can improve the success of the recognition phase, due to the formation of ROI, feature extraction process to be performed is limited to a specific region or area that has been restricted.

In this study, each handwritten documents that have been scanned and automatically crop (the size of $200 \times 500$ pixels) will be divided into grids with each grid size of $100 \times 100$ pixels (see Figure 2 ). The results of this gridding process will provide a total grid as $2 \times 5$ grid for each document of the handwriting. Each grid of each image document will then be carried shape based feature extraction process. Another example of ROI process is shown in Figure 3.

\section{Feature Extraction}

Feature extraction is an important stage of recognition application and pattern analysis. This stage will return the values of the features to be measured or identified as a pattern. With the extraction of features or characteristics, important information of the data (which in this study is in the form of handwritten image data) will be taken and stored in the feature vector [6]. Features that can be extracted in the form of image data including color features, shape, and texture. And in this study, the features will be extracted is based on the representation of the handwritten form.

In Figure 4, the values of the shape based features of the handwritten extraction will be binary values (values ' 0 ' or ' 1 ') to each grid for 
14 Jurnal Ilmu Komputer dan Informasi (Journal of Computer Science and Information), Volume 10, Issue 1, June 2017

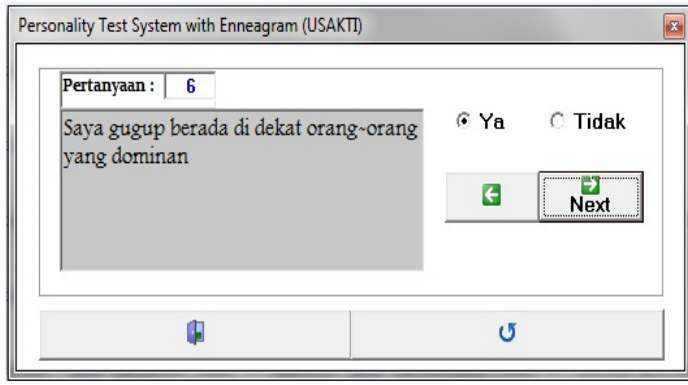

Figure 6. Enneagram Menu

each image, where the value of ' 0 ' will be given if the representation of the grid is the background object, and a value of ' 1 ' if the representation of the grid is a foreground object with a minimum of $15 \%$ of total pixels of each grid is a foreground object [1].

\section{Formation of Cluster}

Formation of clusters that are used in a previous study that is to classify the extracted shape features, in accordance with the number of clusters referenced handwritten form on the science of graphology. The method used is Fuzzy C-Means, the development method of Hard K-Means, where the centroid (center of cluster) determined from the acquisition of membership values search repeatedly with minimal distance. Fuzzy C-Means in their utilization can also be used for medical image segmentation, thus simplifying the diagnostic process as in research of Zhou et al [9]. Fuzzy C-Means formula is as follows :

$$
\begin{array}{r}
J_{m}^{m} \sum_{\substack{k=1 \\
-v_{k} \|^{2}}}^{c} \sum_{k i}^{m} \| x_{i} \\
u_{k i}=\frac{1}{\sum_{l=1}^{c}\left(\frac{\left\|x_{i}-v_{k}\right\|}{\left\|x_{i}-v_{l}\right\|}\right)^{2 /(m-1)}} \\
v_{k}=\frac{\sum_{i=1}^{N} u_{k i}^{m} x_{i}}{\sum_{i=1}^{N} u_{k i}^{m}}
\end{array}
$$

where $X i$ is the image of handwritten to $i$ with a total of $N$ feature vectors, $V k$ is the cluster center (centroid) to $k$ of the $c$ total class, and $J$ is the distance obtained quantitatively. To initialize the beginning, the center of cluster $(V)$ will be randomly selected from the overall total image of the handwriting used. While $u$ is the value of the feature vector of $k$ cluster center up to a total $m$ cluster center.

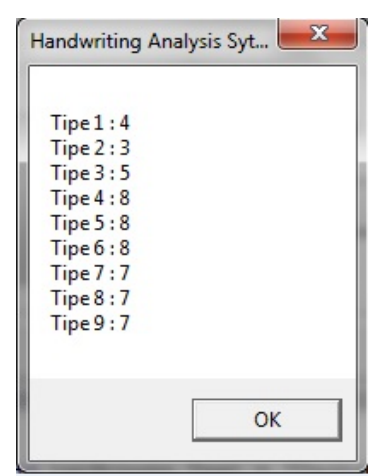

Figure 7. Weight Results of Enneagram

\section{Pattern Recognition}

Pattern recognition is one of the techniques of the science of Artificial Intelligence, which aims to recognize the features or the specific characteristics of data set (both text and image documents) and classifies [3]. Pattern recognition can be done in several ways, one of which is by using Similarity Measures.

Similarity measure is a method that can be used to find the similarity of objects to one another, by calculating the distance among them [4]. As the research conducted Anna Huang in 2008, this study also used the technique similarity measures in recognizing handwritten patterns by calculating the distance between the patterns by using the Euclidean distance formula [4]:

$$
\begin{aligned}
& d(p, q)=d(q, p) \\
& =\sqrt{\left(q_{1}-p_{1}\right)^{2}+\left(q_{2}-p_{2}\right)^{2}+\cdots+} \\
& =\sqrt{\sum_{i=1}^{n}\left(q_{i}-p_{i}\right)^{2}}
\end{aligned}
$$

where $d$ is the total distance between the handwritten image pixel values with each other, $q$ and $p$ are the pixels image.

\section{Interpretation of Graphology}

Graphology is a science which studies reading techniques of human character through handwriting from various viewpoints [8]. Research on the graphology science has been widely used to help figure out a human's personality and character. The experts of graphology (graphologist) states that a handwriting analysis can provide information on: 1) Strengths and weaknesses of one's character; 2) Human's behavior in a given situation; 3) The health condition of psychology, mental, and the ability of a person interactions on the current situation. 
In providing the analysis, the science of graphology has some readings angle from handwriting form category, such as the slope of writing, pressure, size, and spacing writing [10]. Each category has a handwriting analysis of personality and character are different also.

\section{Interpretation of Psychology}

Psychology is defined as the scientific study of the behavior and mental processes of an organism [15]. By scientific meaningful studies conducted and data collected follows a systematic procedure, using psychological tests.

Psychological testing is a structured technique used to produce the examples chosen behavior. Example of this behavior will be used to

TABLE 1.1 HANDWRITTEN FEATURES MAPPING INTO THE ENNEAGRAM (1)

\begin{tabular}{|c|c|c|c|c|c|}
\hline No & $\begin{array}{c}\text { Base- } \\
\text { line }\end{array}$ & Slant & Size & Breaks & $\begin{array}{c}\text { Ennea- } \\
\text { gram } \\
\text { Type }\end{array}$ \\
\hline 1 & Up & $\begin{array}{c}\text { Leaning to } \\
\text { the Left }\end{array}$ & Small & Dashed & 4 \\
\hline 2 & Up & $\begin{array}{l}\text { Leaning to } \\
\text { the Left }\end{array}$ & Small & Connected & 5 \\
\hline 3 & Up & $\begin{array}{l}\text { Leaning to } \\
\text { the Left }\end{array}$ & Large & Dashed & 8 \\
\hline 4 & Up & $\begin{array}{l}\text { Leaning to } \\
\text { the Left }\end{array}$ & Large & Connected & 7 \\
\hline 5 & Up & $\begin{array}{l}\text { Leaning to } \\
\text { the Left }\end{array}$ & Medium & Dashed & 4 \\
\hline 6 & Up & $\begin{array}{l}\text { Leaning to } \\
\text { the Left }\end{array}$ & Medium & Connected & 5 \\
\hline 7 & Up & Vertical & Small & Dashed & 6 \\
\hline 8 & Up & Vertical & Small & Connected & 5 \\
\hline 9 & Up & Vertical & Large & Dashed & 7 \\
\hline 10 & Up & Vertical & Large & Connected & 8 \\
\hline 11 & Up & Vertical & Medium & Dashed & 3 \\
\hline 12 & Up & Vertical & Medium & Connected & 5 \\
\hline 13 & Up & $\begin{array}{l}\text { Leaning to } \\
\text { the Right }\end{array}$ & Small & Dashed & 7 \\
\hline 14 & Up & $\begin{array}{l}\text { Leaning to } \\
\text { the Right }\end{array}$ & Small & Connected & 3 \\
\hline 15 & Up & $\begin{array}{l}\text { Leaning to } \\
\text { the Right }\end{array}$ & Large & Dashed & 3 \\
\hline 16 & Up & $\begin{array}{l}\text { Leaning to } \\
\text { the Right }\end{array}$ & Large & Connected & 1 \\
\hline 17 & Up & $\begin{array}{l}\text { Leaning to } \\
\text { the Right }\end{array}$ & Medium & Dashed & 6 \\
\hline 18 & Up & $\begin{array}{l}\text { Leaning to } \\
\text { the Right }\end{array}$ & Medium & Connected & 3 \\
\hline 19 & Flat & $\begin{array}{l}\text { Leaning to } \\
\text { the Left }\end{array}$ & Small & Dashed & 4 \\
\hline 20 & Flat & $\begin{array}{l}\text { Leaning to } \\
\text { the Left }\end{array}$ & Small & Connected & 6 \\
\hline 21 & Flat & $\begin{array}{l}\text { Leaning to } \\
\text { the Left }\end{array}$ & Large & Dashed & 8 \\
\hline 22 & Flat & $\begin{array}{l}\text { Leaning to } \\
\text { the Left }\end{array}$ & Large & Connected & 9 \\
\hline 23 & Flat & $\begin{array}{l}\text { Leaning to } \\
\text { the Left }\end{array}$ & Medium & Dashed & 6 \\
\hline 24 & Flat & $\begin{array}{l}\text { Leaning to } \\
\text { the Left }\end{array}$ & Medium & Connected & 6 \\
\hline 25 & Flat & Vertical & Small & Dashed & 4 \\
\hline 26 & Flat & Vertical & Small & Connected & 5 \\
\hline 27 & Flat & Vertical & Large & Dashed & 3 \\
\hline
\end{tabular}

make inferences about the psychological attributes of a person [15].

Enneagram is a method that has been proven to be very accurate to describe human personality [13][16]. This is because the method of assessing the personality types based on the experience of someone who happened since early age and see the influence of genetics.

\section{Calculation of Accuracy and Validity}

This stage is the final step, in which each of the results of handwriting analysis using graphology and enneagram questionnaire answers matched:

$\frac{\text { Result of handwriting using graphology }}{\text { Result of handwriting using enneagram }} \times 100 \%$

TABLE 1.2

HANDWRITTEN FEATURES MAPPING INTO THE ENNEAGRAM (2)

\begin{tabular}{|c|c|c|c|c|c|}
\hline No & $\begin{array}{l}\text { Base- } \\
\text { line }\end{array}$ & Slant & Size & Breaks & $\begin{array}{c}\text { Ennea- } \\
\text { gram } \\
\text { Type }\end{array}$ \\
\hline 28 & Flat & Vertical & Large & Connected & 1 \\
\hline 29 & Flat & Vertical & Medium & Dashed & 6 \\
\hline 30 & Flat & Vertical & Medium & Connected & 7 \\
\hline 31 & Flat & $\begin{array}{l}\text { Leaning to } \\
\text { the Right }\end{array}$ & Small & Dashed & 6 \\
\hline 32 & Flat & $\begin{array}{l}\text { Leaning to } \\
\text { the Right }\end{array}$ & Small & Connected & 9 \\
\hline 33 & Flat & $\begin{array}{l}\text { Leaning to } \\
\text { the Right }\end{array}$ & Large & Dashed & 7 \\
\hline 34 & Flat & $\begin{array}{l}\text { Leaning to } \\
\text { the Right }\end{array}$ & Large & Connected & 1 \\
\hline 35 & Flat & $\begin{array}{l}\text { Leaning to } \\
\text { the Right }\end{array}$ & Medium & Dashed & 3 \\
\hline 36 & Flat & $\begin{array}{l}\text { Leaning to } \\
\text { the Right }\end{array}$ & Medium & Connected & 1 \\
\hline 37 & Down & $\begin{array}{l}\text { Leaning to } \\
\text { the Left }\end{array}$ & Small & Dashed & 4 \\
\hline 38 & Down & $\begin{array}{l}\text { Leaning to } \\
\text { the Left }\end{array}$ & Small & Connected & 6 \\
\hline 39 & Down & $\begin{array}{l}\text { Leaning to } \\
\text { the Left }\end{array}$ & Large & Dashed & 8 \\
\hline 40 & Down & $\begin{array}{l}\text { Leaning to } \\
\text { the Left }\end{array}$ & Large & Connected & 6 \\
\hline 41 & Down & $\begin{array}{l}\text { Leaning to } \\
\text { the Left }\end{array}$ & Medium & Dashed & 8 \\
\hline 42 & Down & $\begin{array}{l}\text { Leaning to } \\
\text { the Left }\end{array}$ & Medium & Connected & 6 \\
\hline 43 & Down & Vertical & Small & Dashed & 2 \\
\hline 44 & Down & Vertical & Small & Connected & 9 \\
\hline 45 & Down & Vertical & Large & Dashed & 7 \\
\hline 46 & Down & Vertical & Large & Connected & 5 \\
\hline 47 & Down & Vertical & Medium & Dashed & 2 \\
\hline 48 & Down & Vertical & Medium & Connected & 9 \\
\hline 49 & Down & $\begin{array}{l}\text { Leaning to } \\
\text { the Right }\end{array}$ & Small & Dashed & 4 \\
\hline 50 & Down & $\begin{array}{l}\text { Leaning to } \\
\text { the Right }\end{array}$ & Small & Connected & 6 \\
\hline 51 & Down & $\begin{array}{l}\text { Leaning to } \\
\text { the Right }\end{array}$ & Large & Dashed & 6 \\
\hline 52 & Down & $\begin{array}{l}\text { Leaning to } \\
\text { the Right }\end{array}$ & Large & Connected & 8 \\
\hline 53 & Down & $\begin{array}{l}\text { Leaning to } \\
\text { the Right }\end{array}$ & Medium & Dashed & 6 \\
\hline 54 & Down & $\begin{array}{l}\text { Leaning to } \\
\text { the Right }\end{array}$ & Medium & Connected & 8 \\
\hline
\end{tabular}


16 Jurnal Ilmu Komputer dan Informasi (Journal of Computer Science and Information), Volume 10, Issue 1, June 2017

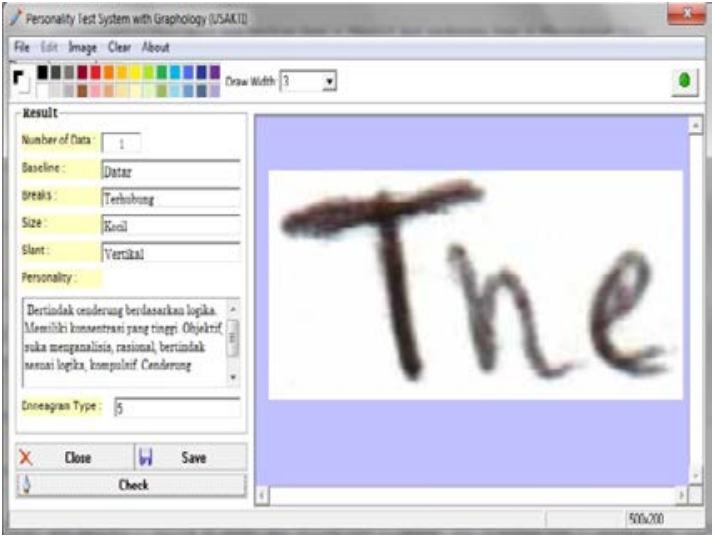

Figure 8. Handwriting Analysis Menu

TABLE 2.1

HANDWRITTEN ANALYSIS RESULTS USING GRAPHOLOGY AND

\begin{tabular}{|c|c|c|c|}
\hline \multicolumn{4}{|c|}{ ENNEAGRAM (1) } \\
\hline \multirow[t]{2}{*}{ No. } & \multirow[t]{2}{*}{ Respondent } & \multicolumn{2}{|c|}{ Personality Type } \\
\hline & & $\begin{array}{l}\text { Enneagram/ } \\
\text { Psychologists }\end{array}$ & Graphology \\
\hline 1 & Marcella & $3 / 7 / 9$ & 3 \\
\hline 2 & ANONYMOUS & 3 & 3 \\
\hline 3 & Nathania & 9 & 7 \\
\hline 4 & ANONYMOUS & $2 / 3 / 5$ & 5 \\
\hline 5 & ANONYMOUS & $5 / 9$ & 9 \\
\hline 6 & ANONYMOUS & $3 / 8$ & 3 \\
\hline 7 & ANONYMOUS & 9 & 4 \\
\hline 8 & ANONYMOUS & 2 & 2 \\
\hline 9 & ANONYMOUS & 4 & 4 \\
\hline 10 & ANONYMOUS & - & - \\
\hline 11 & Zilzikridini & 4 & 9 \\
\hline 12 & Veni Emiriya & 3 & 3 \\
\hline 13 & Yayang Nafisa & 7 & 7 \\
\hline 14 & Vitria R Claudia & $7 / 9$ & 7 \\
\hline 15 & Nadine A.S & 7 & 2 \\
\hline 16 & Sarah & 3 & 1 \\
\hline 17 & Titania Raras N & 4 & 4 \\
\hline 18 & Khumaira A. & $6 / 9$ & 6 \\
\hline 19 & Tara Ayu A.P & 9 & 9 \\
\hline 20 & Niken & 7 & 7 \\
\hline 21 & Nurul Mulya P. & 9 & 9 \\
\hline 22 & Putri & 3 & 3 \\
\hline 23 & Labiba & 7 & 7 \\
\hline 24 & Melinda & 9 & 9 \\
\hline 25 & Nur Fajriyah & $4 / 7 / 9$ & 7 \\
\hline
\end{tabular}

The results of these matches will give system accuracy and prove the validity of the method of graphology in recognizing humas's personality.

\section{Data Collection Technique}

Collecting data in this research through the istribution of questionnaires directly to the various speakers, which in this study were collected totaled 50 data. The questionnaire contains 90 questions and an empty column to fill this handwriting will be processed in software to produce in accordance with the type of personality psychology and graphology.
TABLE 2.2

HANDWRITTEN ANALYSIS RESULTS USING GRAPHOLOGY AND

\begin{tabular}{|c|c|c|c|}
\hline \multicolumn{4}{|c|}{ ENNEAGRAM (2) } \\
\hline \multirow[t]{2}{*}{ No. } & \multirow[t]{2}{*}{ Respondent } & \multicolumn{2}{|c|}{ Personality Type } \\
\hline & & $\begin{array}{c}\text { Enneagram/ Psy- } \\
\text { chologists }\end{array}$ & $\begin{array}{c}\text { Graphol- } \\
\text { ogy }\end{array}$ \\
\hline 26 & Tiara & 7 & 7 \\
\hline 27 & Ranyta Diani & 5 & 3 \\
\hline 28 & Sarah Widiyanti & 6 & 6 \\
\hline 29 & Lady Margaretta & 2 & 4 \\
\hline 30 & Rania Bahasoean & 9 & 9 \\
\hline 31 & Sisilya Eva & 3/7/8 & 8 \\
\hline 32 & Safira & 5 & 5 \\
\hline 33 & Nissa & $1 / 9$ & 1 \\
\hline 34 & Ari Satria & 8 & 8 \\
\hline 35 & Robert Muliawan & 5 & 5 \\
\hline 36 & TiffanyMarcellie & $2 / 6 / 7 / 9$ & 6 \\
\hline 37 & Tiffany & $2 / 9$ & 9 \\
\hline 38 & Qotrunnadya & 9 & 1 \\
\hline 39 & Siti Salediah & 2 & 2 \\
\hline 40 & Namira & 6 & 6 \\
\hline 41 & Petra Mario S. & 2 & 2 \\
\hline 42 & Lea Insani & $5 / 6 / 9$ & 5 \\
\hline 43 & Marcellina & 7 & 7 \\
\hline 44 & Sherli Betris & 1 & 1 \\
\hline 45 & Viola & 2 & 2 \\
\hline 46 & Shazlin & 1 & 1 \\
\hline 47 & Manindya & 9 & 7 \\
\hline 48 & Miranti V & 8 & 8 \\
\hline 49 & Stella Febrina & $1 / 7$ & 1 \\
\hline 50 & RM & 3 & 3 \\
\hline
\end{tabular}

\section{Research Design}

In Figure 5 can be seen that in this study the researchers used comparison of the results of the introduction of personality types based on analysis graphology and psychology (through enneagram methods) to determine the accuracy of the system being developed. The personality characteristics of 11 features cluster referenced handwritten form obtained by reference to the science of graphology [8][11][12] and the results of research conducted by researchers previously [17]. Among the clusters 'Baseline', 'Slant', 'Breaks', and 'Size'. Baseline consists of 'Up', 'Flat', 'Down'. Slant consists of 'Leaning to the Left', 'Leaning to the Right' and 'Vertical'. Size consists of 'Large', 'Small', and 'Medium'. Breaks consists of 'Dashed', 'Connected'. Table 1 is a mapping table of handwriting form features into the enneagram through psychologists analysis results.

\section{Results and Analysis}

From the 50 data collected (Table 2), 1 data is considered not valid because the filling in its questionnaire that do not fit. Thus, the data examined totaled 49, where testing is done using software which has been developed.

The results of the answers in the enneagram menu (Figure 6), then calculated to determine the most weight. The highest weights will determine 
the type of personality that is owned by the respondent.

Figure 7 shows that the respondent data were tested had the greatest weight value on types 4,5 , and 6 . These results will then be matched with the testing of graphology method, which analyze trends owned personality type from the Andwriting to see the shape features.

On the menu at the top (see Figure 8), shows that images of handwritten notes of the respondents will be extracted the shape features with a series of processes, which will then be assessed by a system of personality types and descriptions. Those results will then be matched with the enneagram assessment results :

And from the 49 tested data (1 data is not valid), this study got a match rate of $81.6 \%$ between the personality analysis of psychology to the graphology science. Where these percentages obtained from 40 data were tested with similar results, and 9 data have different results for the personality type (at Table 2). Thus, this study was able to prove that there is a correlation between a human's personality by the shape of her Andwriting, so that in analyzing the behavior, characteristics, psychological condition of someone can through handwriting and not necessarily through psychological tests.

\section{Conclusion}

From these results, the researchers can then provide conclusions include :

Implementation of graphology method in analyzing someone's personality type of handwriting can have the same results with the analysis using enneagram method in psychology, with a match rate of $81.6 \%$. So therefore, the science of graphology has been scientifically proven its validity through this research.

Implementation of graphology in giving analysis of human's personality results can be faster than the application of the enneagram, because graphology analysis requires only handwriting samples with simple sentences and without going through a series of questions and take as many psychological tests with enneagram.

\section{References}

[1] L. Guojun. Multimedia Management Database Systems. Artech House Inc. 1999

[2] D. Pratiwi. The Use of Self Organizing Map Method and Feature Selection in Image Database Classificaton System. International Journal of Computer Science Issues (IJCSI). 2012. Vol.9 Issue 3. No.2 ISSN : 1694-0814
[3] Y.A Absultany. Pattern Recognition using Multilayer Neural Genetic Algorithm. Neurocomputing. Elseiver Science. 2003. 237-247.

[4] A. Huang. Similarity Measures for Text Document Clustering. New Zealand Computer Science Research Student Conference. Christchurch New Zealand. 2008.

[5] R.A Poldrack. Region of Interest Analysis for fMRI. Oxford Journal. Los Angeles USA. 2007. Vol.2. Issue 1. Pp 67-70.

[6] D. Pratiwi, D.D Santika, B. Pardamean. An Application of Backpropagation Artificial Neural Network for Measuring The Severity of Osteoarthritis. International Journal of Engineering \& Technology (IJET-IJENS). 2011. Vol.11. No.3. ISSN : 117303-8585

[7] G. Kim, A. Torralba. Unsupervised Detection of Region of Interest Using Iterative Link Analysis. Massachusetts Institute of Technology. 2009

[8] C. Howard. Graphology. The Pen Publishing Company. Philadelphia. 1922

[9] H. Zhou, G. Schaefer, C. Shi. Fuzzy C-Means Techniques for Medical Image Segmentation. Fuzzy System in Bioinformatics and Computational Biology Studies in Fuzziness and Soft Computing. Springer-Verlag Berlin. 2009. Vol. 242. Pp 257-271. ISSN : 14349922

[10] B. Ludvianto. Grapho for Success : Analisis Tulisan Tangan. PT Gramedia Pustaka Utama. Jakarta. 2013

[11] R. Coll, A. Fornes, J. Liados. Graphological Analysis of Handwritten Text Documents for Human Resources Recruitment. International Conference on Document Analysis and Recognition. IEEE Computer Society. DOI: 10.1109/ICDAR.2009.213.2009.

[12] V, Kamath et al. Development of an Automated Handwriting Analysis System. Asian Research Publishing Network (ARPN) Journal of Engineering and Applied Science. 2011. Vol.6 No.9 ISSN : 1819-6608.

[13] R. Baron, E. Wagele. Eneagram :Mengenal 9 Tipe Kepribadian Manusia dengan Lebih Asyik. PT Serambi Ilmu Semesta. Jakarta. 2014.

[14] D. R. Riso, R. Hudson. The Riso-Hudson Enneagram Type Indicator (RHETI). Version 2.5. Enneagram Institute. New York. 2001. Pp. 1-18. ISBN : 9780-9703824-0-5

[15] A. Poizner. Graphology in Clinical Practice. Psychologica. Spring Burlington. 2004. Vol. 24 No.1.

[16] S. S. Eric, T. Thomas. The Enneagram and Brain Chemistry. The Enneagram Institute. 
18 Jurnal Ilmu Komputer dan Informasi (Journal of Computer Science and Information), Volume 10, Issue 1, June 2017

https://www.enneagraminstitute.com/theenneagram-and-brain-chemistry/ [diakses 2 Januari 2016]

[17] D. Pratiwi, A.B. Ariwibowo, F. Oktaviyanti. Penerapan Ilmu Grafologi dalam
Membangun Piranti Penganalisa Tulisan Tangan melalui Ekstraksi Fitur Bentuk. SNTI IV Universitas Trisakti. Jakarta. 2014. 82-1 82-6. ISSN: 2355-925X 